\title{
Major Species and Anatomical Characteristics of the Wood Used for National Use Specified in Yeonggeon-Uigwes of the Late Joseon Dynasty Period ${ }^{1}$
}

\author{
Hyun Mi LEE $\mathbb{D}^{2 \dagger} \cdot$ Jae Soo BAE $^{3}$
}

\begin{abstract}
To find out the wood species used in national wood structures in the late Joseon Dynasty, 11 volumes of Yeonggeon-Uigwes were reviewed. It was confirmed that the wood was mainly used for the repair and restoration of palaces, shrines, and fortresses. In the 17th to 20th centuries, the wood species specified in Yeonggeon-Uigwes have revealed either hardwood or softwood. As hardwood species, Juglans mandshurica, Zelkova serrata, Fraximus rhynchophylla, Betula schmidtii, Paulownia coreana, or Quercus spp. (Quercus aliena; $Q$, variabilis; $Q$, dentata; $Q$ acutissima; $Q$, mongolica; $Q$, serrata) were used. As softwood species, Pinus densiflora and Pimus koraiensis were used. Investigation of the wood species is important part because the same species is required as a principle when reparing cultural heritage. In this study, the anatomical images of the wood species were investigated for some samples which were taken from the same species that has been stored in the wood specimen room of the National Institute of Forest Science, instead of the actual wood material used. It was possible to find out the wood species of each member in the wooden cultural heritage buildings by reviewing the Yeonggeon-Uigwes in the late Joseon Dynasty, and the anatomical images of the wood species required for determining the wood species in the repair or restoration of the buildings.
\end{abstract}

Keywords: Joseon Dynasty, Yeonggeon-Uigwes, wood architecture, wood species, anatomical characteristics

\section{INTRODUCTION}

Uigwe is a book that has the historical records as references for future generations, of the details of events, expenses, participants, ritual procedures, and discussion about prizes and awards after events when there was a big event for the royal family or state of the Joseon Dynasty (Bae, 2000). Currently, the places to access and read Uigwes include Seoul National
University's Kyujanggak, Jangseogak of the Korea Institute of Spirit and Culture, and the National Assembly Library.

According to the data from the collections of Jangseogak and Kyujanggak, "Changgyeonggung Suriso Uigwe (1633)" and "Changdeokgung Changgyeonggung Suridogam Uigwe (1652, Hyojong 3)" are the first records for palaces in the mid-17th century. In particular, Changgyeonggung Suriso Uigwe is the oldest existing Uigwe among those

${ }^{1}$ Date Received March 31, 2021, Date Accepted July 22, 2021

2 Division of Wood Engineering, National Institute of Forest Science, Seoul 02455, Republic of Korea

${ }^{3}$ Department of Future Forest Stately, National Institute of Forest Science, Seoul 02455, Republic of Korea

$\dagger$ Corresponding author: Hyun Mi LEE (e-mail: leehm2986@korea.kr, ORCID: 0000-0002-1031-3348) 
Major Species and Anatomical Characteristics of the Wood Used for National Use Specified in Yeonggeon-Uigwes of the Late Joseon Dynasty Period

related to architecture (Hong, 2012). Changgyeonggung Palace, which was destroyed during the Japanese Invasion of Korea in 1592, was reconstructed during the Gwanghaegun period. However, its buildings of Tongmyeongjeon Hall, Yanghwadang Hall, and Hwangyeongjeon Hall were destroyed again by Lee Kwal's Rebellion in the $2^{\text {nd }}$ year of King Injo. In the 18th century, the rituals in repairing and rebuilding a Eojaesil chamber, Jungdang, and Jaesil were recorded in Gyeongmogung Gaegeondogam Uigwe (1776), while "Jinjeon Jungsudogam Uigwe (1748)" is the records of the process of repairing Youngheejeon as a royal portrait hall and enshrining King Sukjong's royal portraits. Hwaseong Fortress Uigwe (1796) is a book in which the construction of a new castle in Hwaseong, Gyeonggi Province and organization of the surroundings, consisting of a total of 8 books in 10 volumes including 1 volume, 6 main parts and 3 appendices. Hwaseong Fortress Uigwe is considered the most extensive and detailed Uigwe (Kim, 2005; Kim, 2009). 'Injeongjeon Jungsu Uigwe" (1857) is a book in which the repairing process of the Injeongjeon Hall of Changdeokgung Palace was recorded in the 19th century. Changgyeonggung Yeonggundogam Uigwe (1834) is a record of the reconstruction of Changgyeonggung Palace, and Changdeokgung Yeong-gundogam Uigwe (1834) is a record of the construction of 370 squares of Changdeokgung Palace. "Gyeongbokgung Changdeokgung Junggeondogam Uigwe" (1900) is a record of building an additional room each in Sunwonjeon of Gyeongbokgung Palace and Changdeokgung Palace. In the 20th century's "Junghwajeon Yeonggundogam Uigwe" and "Gyeongungung Junggeondogam Uigwe", the construction process of Junghwajeon in the Gyeongungung Palace was recorded (Lee, 2002; Kim et al., 2010; Park et al., 2018).

Summarizing the composition of the species identified in the Yeonggeon-Uigwes, the use of Pinus densiflora $(73 \%)$ increased prominently during the earlyand mid-Joseon dynasty, including Quercus spp.
(14\%) and Zelkova serrata (9\%). During the late Joseon Dynasty, most of the building materials were Pinus densiflora (88\%), which was mostly used in wooden buildings such as Changdeokgung Palace and Gyeongbokgung Palace of the Joseon Dynasty (Park and Lee, 2007). This study was conducted to identify the primary wood species used in buildings during the late Joseon Dynasty (17th century to the early 20th century) through Yeonggeon-Uigwes and present the anatomical characteristics of wood species.

\section{MATERIALS and METHODS}

\subsection{Testing materials}

Wood species that were used for constructions of wooden buildings of royal palaces in the Joseon Dynasty were selected based on 11 volumes of Yeonggeon Uigwes during the late Joseon Dynasty (17th century to 20th century): Changgyeonggung Suriso Uigwe and Changdeokgung Changgyeonggung Suridogam Uigwe from the 17th century; Gyeongmogunggaegeondogam Uigwe, Jinjeonjungsudogam Uigwe, and Hwaseong Seongyeok Uigwe from the 18th century; Injeongjeon Jungsu Uigwe, Changgyeonggung Yeonggeondogam Uigwe, Changdeokgung Yeonggeondogam Uigwe, and Gyeongbokgung Changdeokgung Junggeondogam Uigwe from the 19th-century; and Junghwajeon Yeonggeondogam Uigwe and Gyeongungung Junggeondogam Uigwe from the 20th century. The anatomical characteristics of the selected wood species were organized using the wood samples stored in the wood specimen room of the National Institute of Forest Science. The wood species recorded in the Yeonggeon-Uigwes are Pinus densiflora, Pinus koraiensis, Juglans mandshurica, Zelkova serrata, Fraximus rhynchophylla, Betula schmidtii, Paulownia coreana, Quercus aliena, Quercus variabilis, Quercus dentata, Quercus acutissima, Quercus mongolica, and Quercus serrata. 


\subsection{Investigation methods}

Microscope slides were prepared with 3 sections of wood specimens for miscroscopic observations of wood tissue specimens. The collected samples were slightly hand-cut using razor blades or cut using a microtome to get three timber sections (cross-section, radial section, tangential section). The samples were prepared in the order of softening, slice making, safranin stain, dehydration of alcohols, and finally mounting with Canada balsam.

\subsection{Histological analysis}

The fabricated preparat was used to observe the structure and characteristics of wood cells using an optical microscope (Carl Zeiss, DE/Axio imger A1). The identification of wood species was performed based ontissue characteristics that appeared in three sections.

\section{RESULTS and DISCUSSION}

\subsection{Major species by age}

The details of procurement by era in government constructions during the late Joseon Dynasty was divided into major categories and subcategories, and various types of raw materials were used, ranging from large timber to small wood materials. The species specified in Changgyeonggung Suriso Uigwe in the 17th century includes Juglans mandshurica, Quercus spp., etc.

Changdeokgung-Changgyeonggung-Suridogam specifies Quercus spp., Fraxinus rhynchophylla, and Pinus densiflora. In the 18th century, the wood species specified in Jinjeon Jungsudogam Uigwe included Betula schmidtii, Paulownia coreana, Juglans mandshurica, and Pinus densiflora. Gyeongmogung Gaegeondogam Uigwe included Pinus densiflora and Betula schmidtii, and Hwaseong Seongyeok Uigwe included Pinus densiflora and Zelkova serrata. The wood species specified
Table 1. Yeonggeon-Uigwe National Wood Species by Century

\begin{tabular}{ccccc}
\hline Species/Century & 17th & 18th & 19th & 20th \\
\hline \hline Pinus densiflora & $\circ$ & $\circ$ & $\circ$ & $\circ$ \\
Pinus koraiensis & & & $\circ$ & \\
Juglans & & & & \\
mandshurica & $\circ$ & $\circ$ & $\circ$ & \\
Zelkova serrata & & & & $\circ$ \\
$\quad$ Faxinus & $\circ$ & & & \\
rhynchophylla & $\circ$ & & $\circ$ & \\
Betula schmidtii & & $\circ$ & & \\
Paulwonia coreana & & $\circ$ & & \\
Quercus spp. & $\circ$ & $\circ$ & $\circ$ & $\circ$ \\
\hline
\end{tabular}

in the 19th century Changdeokgung Yeonggeondogam Uigwe included Pinus densiflora, Fraxinus rhynchophylla, Quercus spp., and Juglans mandshurica. Changgyeonggung Yeonggeondogam Uigwe included Pinus koraiensis, Fraxinus rhynchophylla, and Quercus spp. Injeongjeon Jungsu Uigwe included Quercus spp., while Gyeongbokgung Changdeokgung Junggeondogam Uigwe specified Quercus spp. and Fraxinus rhynchophylla. The wood species specified in the Junghwajeon Yeonggeondogam Uigwe of the 20th century included Zelkova serrata, Pinus densiflora, Quercus spp., while Gyeongungung Junggeondogam Uigwe included Pinus densiflora, Quercus spp., etc. (Eom and Lee, 2018; Jeon et al., 2020).

Pinus densiflora and Quercus spp. were recorded as species used throughout the 17th - 20th centuries (Table 1). Specifically, these major species were used for large size timbers, medium size timbers, small size timbers, Nuju (timber columns), Daeyeon (large sedan chair), Jungyeon (medium sedan chair), Soyeon (small sedan chair), pillar, pine board, rafters, rectangular lumber, and wood panels. Although the terms of major wood materials recorded in the Yeonggeon-Uigwes are consistently referred to as one name, many different names were used as per Uigwes (Kim et al., 2007). 
Major Species and Anatomical Characteristics of the Wood Used for National Use Specified in Yeonggeon-Uigwes of the Late Joseon Dynasty Period

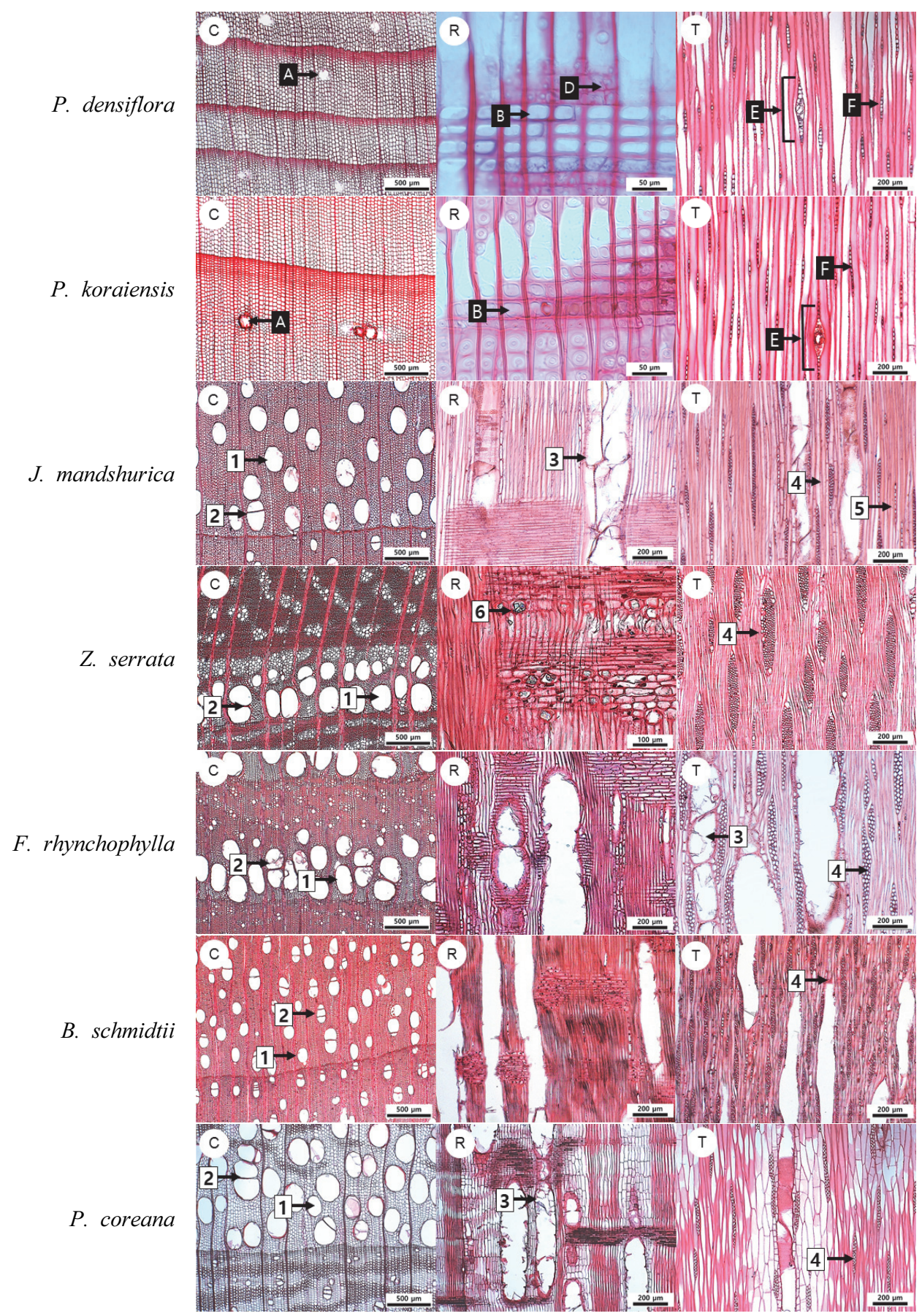

Fig. 1. Three dimensional light microscopic images (I).

A: axial intercellular canal, B: window-like pit, D: dentate thickening, E: fusiform ray, F: uniseriate ray, 1: solitary vessel, 2: vessels in radial multiple, 3: tylosis, 4: multiseriate ray, 5: uniseriate ray, 6: crystal 


\subsection{The anatomical characteristics of wood species}

Fig. 1 and 2 show results from the observation of three sections of species recorded in the Yeonggeon Uigwe. The identified species were two softwoods and eleven hardwoods. In Pinus densiflora and Pinus kor- aiensis, intercellular canals, window-like pits, and uniseriate and fusiform rays were observed clearly, and crystals were observed in ray parenchyma cells of Zelkova serrata among hardwoods, which are the consistent results from previous studies (IAWA, 1989; Han et al., 2017; Kim et al., 2018; Kwon et al., 2020). Other characteristics are shown in Table 2.

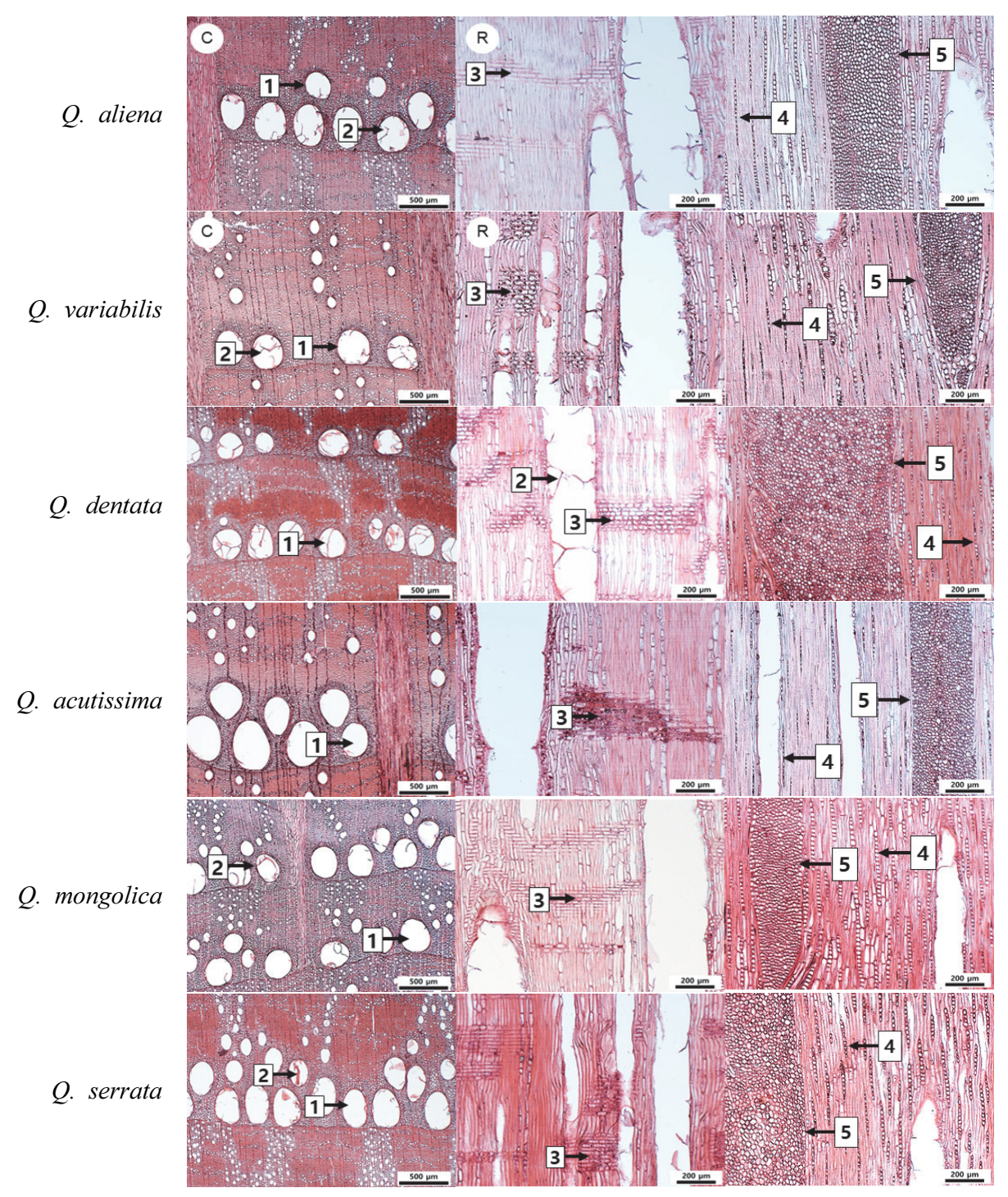

Fig. 2. Three dimensional light microscopic images (II).

1: solitary vessel, 2: tylosis, 3: procumbent ray cell, 4: uniseriate ray, 5: broad ray 
Major Species and Anatomical Characteristics of the Wood Used for National Use Specified in Yeonggeon-Uigwes of the Late Joseon Dynasty Period

Table 2. Anatomical characteristics of wood species in the Yeonggeon-Uigwe

\begin{tabular}{|c|c|c|c|c|c|c|c|c|c|}
\hline Section & Component & P. densiflora & P. koraiensis $J$. & I. mandshurica & Z. serrata & F. rhynchophylla & B. schmidtii & P. coreana & Quercus spp \\
\hline \multirow[t]{6}{*}{ Cross } & $\begin{array}{l}\text { Axial intercellular } \\
\text { canal }\end{array}$ & ० & ० & & & & & & \\
\hline & $\begin{array}{l}\text { Ring-porous } \\
\text { wood }\end{array}$ & & & & ० & ० & $\circ$ & $\circ$ & ० \\
\hline & $\begin{array}{l}\text { Diffuse-porous } \\
\text { wood }\end{array}$ & & & $\circ$ & & & ० & & \\
\hline & Solitary vessel & & & ० & $\circ$ & $\circ$ & $\circ$ & $\circ$ & $\circ$ \\
\hline & $\begin{array}{l}\text { Vessels in radial } \\
\text { multiple }\end{array}$ & & & $\circ$ & $\circ$ & ० & & ० & \\
\hline & Tylosis & & & ० & & $\circ$ & & $\circ$ & $\circ$ \\
\hline \multirow[t]{4}{*}{ Radial } & window-like pit & o & o & & & & & & \\
\hline & $\begin{array}{l}\text { dentate } \\
\text { thickening }\end{array}$ & ० & & & & & & & \\
\hline & $\begin{array}{l}\text { procumbent ray } \\
\text { cell }\end{array}$ & & & ० & $\circ$ & ० & ० & ० & ० \\
\hline & $\begin{array}{l}\text { Crystal in ray } \\
\text { parenchyma cell }\end{array}$ & & & & ० & & & & \\
\hline \multirow[t]{4}{*}{ Tangential } & fusiform ray & ० & O & & & & & & \\
\hline & uniseriate ray & ० & ० & ० & & ० & ० & & \\
\hline & multiseriate ray & & & ० & o & ० & ० & o & o \\
\hline & $\begin{array}{l}\text { Rays of two } \\
\text { distinct sizes }\end{array}$ & & & & & & & & o \\
\hline
\end{tabular}

\section{CONCLUSION}

Two softwoods and 11 hardwoods, as wood species used in national wood structures, were recorded in 11 volumes of Yeonggeon-Uigwes. Among wood species used during the 17th to 20th centuries, Pinus densiflora was the predominant species used. According to the Cultural Heritage Administration, it is specified that all wood materials of the wooden cultural heritage should be investigated for wood species when dismantling them. The basic principle of repairing cultural heritage is to restore the original form and to repair or replace them with the same wood species for the same material. Hence, the investigation of species is an important part. Through this study, major species used in wooden cultural heritage during the late Joseon Dynasty were organized by age, and primary anatomical data of wood species were prepared for the expected repairs and restoration in the future.

\section{ACKNOWLEDGMENT}

This study is based on the results from studies (2018-2021) on the transition process of national forest policies from the late Joseon Dynasty to the present, conducted by National Institute of Forest Science.

\section{REFERENCES}

Bae, J.S. 2000. The procurement system and forest management of Yeonggeon-Uigwe wood for national use in the late Joseon period. Forest and culture collections 8: 171-187.

Eom, Y.J., Park, B.D. 2018. Wood speices identification of documentary woodblocks of Songok Clan of the Milseong Park, Gyeongju, Korea. Journal of the Korean Wood Science and Technology 46(3): 270-277.

Hong, H.D. 2012. A study on the repair by moving 
buildings of the Changdeokgung palace and the Changgyeonggung palace in the 17th century. MA.(Ms.) Thesis, pp. 1-75.

Han, Y.J., Kim, M.J., Lee, H.M., Kang, J.T., Eom, C.D. 2017. Comparison of cellular anatomical physical and mechanical properties between Dahurian Larch and Japanese Larch. Journal of the Korean Wood Science and Technology 45(5): 525-534.

IAWA Committee. 1989. IAWA list of microscopic features for hardwood identification. IAWA Bull.n.s. 10:219-332.

Jeon, W.S., Lee, H.M., Park, J.H. 2020. Comparison of anatomical characteristics for wood damaged by Oak Wilt and sound wood from Quercus mongolica. Journal of the Korean Wood Science and Technology 48(6): 807-819.

Kim, D.W., Lee, K.G., Hong, S.J. 2007. A technical study of Korean Architecture through the analysis of the Yeonggeon-Uigwe in the Joseon Dynasty. Korea Basic Science Research Suppot Project. National Research Foundation of Korea, pp. 1-135. Kim, D.W., Lee, K.Y., Lee, K.G., Kim, W.J., Lee, K.M., Lee, H.W., Kim, D.K., Hong, S.J., Lee, Y.N., Jeong, J.N., Cho, S.S., Cho, J.M., Kang, S.W. 2010. YeonggeonUigwe: Architecture of the Joseon Dynasty Recorded in Uigwe. YeonggeonUigwe committee, pp. 171-238. Kim, M.J., Seo, J.W., Kim, B.R. 2018. Anatomical characteristics of Korea Red Pines according to provinces. Journal of the Korean Wood Science and Technology 46(1): 100-106.

Kim, W.J. 2005. History of architectural economy in the late Josen Dynasty. Korean Studies Information Co. Ltd.

Kim, K.T. 2009. A study on procurement of construction materials in the HwaSeong construction project. The Korea Institute of Building Construction 9(6): 183-1888.

Kwon, O.K., Kim, N.H., Kim, J.S., Seo, J.W., Jeong, Y.J. 2020. Wood Anatomy, pp. 48-104.

Kyujanggak Institute for Kroean Studies. Kyujanggak Library. https://kyu.snu.ac.kr

Lee, K.Y. 2002. A study on the wood and woodwork in the construction of the government managed building in the late of Chosun Dynsty. Ph.D Thesis, pp. 1-160.

Park, J.H., Oh, J.E., Hwang, I.S., Jang, H.U., Choi, J.W., Kim, S.C. 2018. Study on species identification for pungnammun gate(Treasure 308) in Jeonju, Korea. Journal of the Korean Wood Science and Technology 46(3): 278-284.

Park, W.K., Lee, K.H. 2007. Changes in the species of woods used for Korean Ancient and historic architectures. Journal of Architectural History (Periodic Publication No. 524) 16(1): 9-28. 
Major Species and Anatomical Characteristics of the Wood Used for National Use Specified in

Yeonggeon-Uigwes of the Late Joseon Dynasty Period

\section{APPENDIX}

(Korean Version)

\section{영건의궤 기록을 활용한 조선후기 국용목재의 주요 수종 조사 및 해부학적 특징}

초록: 조선후기 국용목재에 사용된 수종을 파악하기 위하여 영건의궤 조선후기 11 종의 영건에 명시된 수종을 분석하였다. 주요 용도로는 궁궐, 제실, 사묘, 성곽의 수리와 보수 공사에 사용된 것으로 파악되었다. 17세기 20세기 영건의궤에 명시된 수종 중 활엽수재로는 가래나무, 느티나무, 물푸레나무, 박달나무, 오동나무, 참나무류(갈참나무, 굴참나무, 떡갈나무, 상수리나 무, 신갈나무, 졸참나무)가 확인되었으며, 침엽수재로는 소나무와 잣나무가 확인되었다. 문화재를 수리할 때에는 동일 수종을 원칙으로 하기 때문에 수종 조사는 중요한 부분이다. 각 수종에 대한 목재해부학적 이미지는 실제 사용된 목부재를 대신해서 국립산림과학원 목재표본실에 소장 되어있는 같은 수종 재감을 활용하였다. 조선후기 영건의궤 편역본을 통하여 목조문화재 건축물에 사용된 주요 수종을 알 수 있었으며, 수리·보수 시 사용될 목재 수종을 판정하는 데 필요한 목재해부학적 이미지를 마련하였다.

\section{1. 서론}

의궤란 조선시대 왕실이나 국가에 큰 행사가 있을 때 후세에 참고하도록 하기 위하여 그 일의 전말, 소요경비, 참가인원, 의식절차, 행사 후의 논상(論常) 등을 기록하여 놓은 책으로 종류가 다양하다(Bae, 2000). 현재 의궤를 열람할 수 있는 곳은 서울대학교 규장각과 한국정신문화연구원 장서각, 그리고 국회도서관 등이다.

소장처인 장서각과 규장각의 자료에 의하면, 17 세기 중반 궁궐에 관한 자료로「창경궁수리소의궤(昌慶宮修理所儀軌, 1633)」 와「창덕궁창경궁수리도감의궤(昌德宮昌慶宮修理都監儀軌, 1652 , 효종3)」가 가장 앞서는 자료이다. 특히 창경궁수리소의궤는 건축 관련 의궤 중 현존하는 가장 오래된 것이다(Hong, 2012). 임진왜란으로 소실된 창경궁은 광해군 때 중건되나 다시 인조 2 년 이괄의 난으로 통명전, 양화당, 환경전 일곽이 소실되었다. 18 세기「경모궁개건도감의궤(景慕宮改建都監儀軌, 1776)」는 어재실, 정당, 재실을 보수, 개건할 때의 의례를 기록하였고「진전중수도감의궤(眞殿重修都監儀軌, 1748)」는 진전인 영희전을 중수하고 숙종의 어진을 봉안한 과정을 기록하였다. 「화성성역의궤(華城城役儀軌, 1796)」는 경기도 화성에 새로운 성을 건설하 면서, 성을 쌓고 주변을 정리한 내용을 일일이 기록한 책으로써 권수 1 권과 본편 6 권, 부편 3 권 합이 10 권, 8 책으로 되어 있다. 화성성역의웨는 의궤들 중에서 가장 방대하고 자세하게 기록되어 있는 것으로 손꼽힌다(Kim, 2005; Kim, 2009). 19세기 「인정전중수의궤(仁政殿重修儀軌, 1857)」는 창덕궁 인정전을 중순한 과정을 기록한 책이다.「창경궁영건도감의궤(昌慶宮營建 都監儀軌), 1834)」는 창경궁을 중건한 사실을 기록한 의궤이고「창덕궁영건도감의궤(昌德宮營建都監儀軌, 1834)」는 창덕궁 370 여 칸을 영건한 기록이다. 그리고「경복궁창덕궁중건도감의궤(景福宮昌德宮增建都監儀軌, 1900)」는 경복궁과 창덕궁의 선원전을 각 1실씩 증건한 내용을 기록한 의궤이다. 20세기「중화전영건도감의궤(中和殿營建都監儀軌, 1904)」와「경운궁중건 도감의궤(慶運宮重建都監儀軌, 1906)」는 경운궁 중화전의 신축공사 과정을 기록한 의궤이다(Lee, 2002; Kim et al., 2010; Park et al., 2018).

영건의궤에서 확인된 시대별 수종 구성을 요약하면, 조선시대 전·중기에는 소나무(Pinus. densiflora, $73 \%$ ), 참나무(Quercus $\mathrm{spp}, 14 \%$ ), 느티나무(Zelkova. serrata, $9 \%$ )로 소나무의 사용이 두드러지게 증가한 것으로 나타났다. 조선후기에는 건축부재의 대부분이 소나무 $88 \%$ )이고 조선시대 창덕궁과 경복궁 같은 궁궐 목조건물에는 소나무가 대부분 사용이 되었다(Park and Lee, 2007). 본 연구는 영건의궤를 통해 조선후기(17세기 20세기 초) 건축물에 사용된 주요 수종을 밝히고, 각 수종에 대한 목재해부 학적 특징을 제시하기 위해 수행되었다.

\section{2. 재료 및 방법}

\section{1. 공시재료}

조선후기(17세기 20세기) 영건의궤(17세기 창경궁수리소의궤, 창덕궁창경궁수리도감의궤, 18 세기 경모궁개건도감의궤, 진전중수도감의궤, 진전중수도감의궤, 화성성역의궤, 19 세기 인정전중수의궤, 창경궁영건도감의궤, 창덕궁영건도감의궤, 경복 
궁창덕궁중건도감의궤, 20 세기 중화정영건도감의궤, 경운궁중검도감의궤) 11 종을 통하여 조선시대 왕실의 각종 목조건축물 공사에 사용된 수종을 선정하였다. 선정된 수종의 목재해부학적 특징은 국립산림과학원에서 보유하고 있는 목재 표본실 재감을 활용하여 정리하였다. 영건의궤에서 확인된 수종은 소나무(Pinus densiflora), 잣나무(Pinus koaiensis), 가래나무(Juglans mandshurica), 느티나무(Zelkova serrata), 물푸레나무(Faxinus rhynchophylla), 박달나무(Betula schmidtii), 오동나무 (Paulownia coreana), 참나무(갈참나무(Q.uercus aliena), 굴참나무(Q.uercus variabilis), 떡갈나무(Q.uercus dentata), 상수리 나무(Q.uercus acutissima), 신갈나무(Q.uercus mongolica), 졸참나무(Q.uercus serrata)이다.

\section{2. 조사방법}

시편의 목재조직 현미경 관찰을 위해서 목재 3 단면의 슬라이드를 제작하였다. 채취한 시편은 면도날을 이용하여 얇게 절삭 (hand-cutting)하거나 마이크로톰을 활용하여 목재의 3 단면(횡단면, 방사단면, 접선단면) 절편을 재단하였다. 프레파라트는 연화 처리, 절편제작, safranine으로 염색, 알콜 탈수, Canada balsam으로 봉입하는 순으로 제작하였다.

\section{3. 조직학적 분석}

제작된 프레파라트는 광학현미경(Carl Zeiss, DE/Axio imger A1)을 이용하여 목재 세포의 구조 및 특징을 관찰하였고, 3단면에 나타나는 조직 특성으로 수종 식별을 실시하였다.

\section{3. 결과 및 고찰}

\section{1. 시대별 주요 수종}

조선후기 관영건축공사의 시대별 조달 내역에는 대분류와 소분류로 나누어졌고, 대재목으로부터 소재목에 이르기까지 다양한 종류의 원재가 사용되었다. 17세기 창경궁수리소의궤에 명시된 수종은 가래나무(추목)와 참나무류(진목 또는 진장목) 등이 있다. 창덕궁창경궁수리도감은 참나무류, 물푸레나무(청태목 또는 수청목), 소나무(문횡송목)가 있다. 18세기 진전중수도감의궤 에 명시된 수종은 박달나무, 오동나무, 가래나무, 소나무로 해석되었다, 경모궁개건도감의궤는 소나무, 박달나무가 있었고, 화성성역의궤는 소나무, 느티나무 등이 명시되었다. 19세기 창덕궁영건도감의궤에 명시된 수종은 소나무, 물푸레나무, 참나무류, 가래나무 등이다. 창경궁영건도감의궤는 잣나무(백자판), 물푸레나무, 참나무류이다. 인정전중수의궤 편역에서는 참나무류로 해석되었고, 경복궁창덕궁중건도감의궤는 참나무, 물푸레나무로 명시되었다. 20세기 중화전영건도감의궤에 명시된 수종은 느티 나무, 소나무, 참나무류로 해석되었고, 경운궁중건도감의궤는 소나무, 참나무류 등이다(Eom and Lee, 2018; Jeon et al., 2020).

소나무와 참나무류는 17세기 20세기 전체에 활용되었던 수종으로 기록되었다(Table 1). 주요 수종에 대한 목재 공급 내역의 종류는 대부등, 중부등, 소부등, 누주, 대연, 중연, 소연, 기둥, 송판, 서까래, 각재, 판재 등에 사용되었다. 영건의궤에 기록된 중요 목부재의 용어는 일관되게 한 명칭으로 불리는 것도 있지만 많은 부재들이 의궤마다 다르게 불리는 명칭이 있었다(Kim et al., 2007).

\section{2. 목재해부학적 특징}

Fig. 1,2 는 영건의궤에 기록된 수종들의 3 단면 관찰 결과이다. 확인된 수종은 침엽수 2점과 활엽수 11 점이었다. 소나무와 잣나무에서는 수직세포간구, 창상벽공, 단열 및 방추형방사조직 등이 뚜렷한 형태가 관찰되었고, 활엽수재 중 느티나무 방사유세 포에서는 결정(crystal)이 관찰되어 선행 연구와 같은 결과를 보였다(IAWA, 1989; Han et al, 2017; Kim et al, 2018; Kwon et al., 2020). 이 외에 특징들은 Table 2와 같다.

\section{4. 결론}

영건의궤 11 종에 대한 목부재를 조사한 결과 침엽수 2 점과 활엽수 11 점이라는 기록을 발견하였고, 17 세기에서 20 세기까지 사용된 수종으로 가장 큰 비중을 차지하는 수종은 소나무였다. 문화재수리표준시방서(Culture Heritige Administration)에 따르 면 목조문화재 해체 시 모든 부재에 대하여 수종을 조사하도록 명시되어 있다. 문화재 수리의 기본 원칙은 원형을 복원하고 같은 재질의 동일 수종으로 수리나 교체를 원칙으로 하고 있기 때문에 수종 조사는 중요한 부분이다. 본 연구를 통해 조선후기 목조문화재에 사용된 주요 수종을 시대별로 정리하고 향후 예상되는 수리·보수 시 사용될 수종에 대한 목재해부학적 기초자료를 마련하였다. 